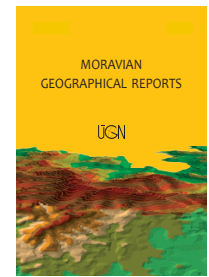

MORAVIAN GEOGRAPHICAL REPORTS

\title{
An evaluation of soil retention potential as an important factor of water balance in the landscape
}

\author{
Zdena KRNÁČOVÁ a *, Juraj HREŠKO ${ }^{b}$, Miriam VLACHOVIČOVÁ a
}

\begin{abstract}
The ability of soil to retain water in its profile is one of the most important soil functions. It is expressed as the water storage capacity or retention capacity of the soil, and it is primarily affected by the physical properties of the soil. Given the fact that the direct measurement of hydrological data for the soil is very difficult in terms of capacity, statistically expressed pedotransfer functions (PTF) are currently used for the indirect estimation of hydrolimits. The data most commonly used for the PTF are easy-to-measure and usually readily available soil data on particle size, bulk density, organic carbon and morphometric parameters of the environment (e.g. slope of the relief, etc.). The listed pedotransfer functions are deficient for the complex evaluation of soil cover; given disagreements about the attributes, they cannot be directly used for the vector database of classified soil-ecological units in the Slovak Republic. Therefore, we have created a model of an algorithm from selected parameters compatible with the vector database of classified soil-ecological units, which also allows for the spatial distribution of the cumulative coefficient of water retention capacity $(C W R C)$ for the soils of the $S R$. The results of this evaluation are presented using case studies of the areas of Levoča and Hriňová.
\end{abstract}

Key words: water retention capacity, soil-ecological units, physical parameters, granularity, soil quality, relief morphometric parameters, Slovakia

Article history: Received 30 September 2015; Accepted 6 June 2016; Published 30 September 2016

\section{Introduction}

Soil is a crucial element affecting the overall capacity of landscape hydric potential. Its importance is understood not only for ensuring conditions for biomass production, but it is also a significant factor of ecosystem functioning and providing for the needs of human society. Soil functions have been defined from different perspectives by many renowned authors (Blum, 1990; Yaalon and Arnold, 2000; Bedrna, 2002; Loveland and Thompson, 2002). The EU Framework Directive on Soil Protection (European Commission, 2006) considers the ecological, socio-economic and cultural soil functions. These functions are biomass production, accumulation, filtration, transformation of nutrients, substances and water, carbon reservoir, reservoir of biodiversity, physical and cultural environment for anthropogenic activities, source of raw materials, and preservation of geological and archaeological heritage.

The importance of ecosystem evaluation is based mainly on economic and social values for society, and it is a result of a lack of appreciation of the dependence of society on the functioning ecosystem services, sources of biodiversity and the multifunctional nature of the resources used (Swanson and Barbier, 1992). The evaluation of environmental functions is always difficult and complicated as it considers inputs from many influences and factors. In terms of the needs of human society, however, the multi-functionality of soil has to be expressed in some way. Each soil function has to be assessed separately, as some of the functions are in mutual contradiction (e.g. retention and infiltration functions) (Bujnovský et al., 2009; Brodová, 2008).

Long-term research studies indicate which soil parameters are crucially dominant for the individual soil functions: physical characteristics are important for hydric functions, chemical soil parameters are important for ecological and stabilisation functions. The degradation-stabilisation function slightly depends on the majority of soil properties. In the assessment of the production potential mutual conditions are important, and they accumulate influences of all soil properties and parameters. Dominant among all soil characteristics is granularity, which affects all the other soil parameters.

\footnotetext{
${ }^{a}$ Institute of Landscape Ecology, Slovak Academy of Sciences, Bratislava, Slovak Republic (*corresponding author: Z. Krnáčová, e-mail: zdena.krnacova@savba.sk)

${ }^{\mathrm{b}}$ Department of Ecology and Environmental Sciences, Faculty of Natural Sciences, Constantine the Philosopher University, Nitra, Slovak Republic
} 
The ability of the soil to retain water in its profile is one of the most important soil functions. It is expressed as water storage capacity or the retention capacity of soil, and it is affected especially by soil physical properties. These are determined mainly by granularity, structure, soil depth and parameters of soil subtype. The soil retention potential is largely determined also by morphometric parameters of relief. Water storage capacity, together with infiltration rate, determine the resistance of the environment to surface runoff or water stagnation on the surface of soils after torrential or heavy rains. Both of these soil characteristics or functions contribute to the ability of the environment to withstand or to cope with floods, even though they actually influence each other in the opposite way: a high infiltration rate (observable particularly in sandy soils) generally means low water storage capacity, and high water storage capacity is typical for heavy soils with a low rate of natural infiltration. Thus, soils contribute to flood prevention and control either directly through the abovementioned characteristics and functions, or indirectly through the co-influence with other elements and features of the environment.

\section{Theoretical background}

Retention capacity can be expressed by the hydrolimits of field capacity. Field capacity is a hydrolimit limiting the water content between gravitation and capillary water and corresponds to the pressure of $2.0-2.9 \mathrm{pF}^{1}$ (Antal, 1999). Given the fact that the direct measurement of soil hydrological parameters is very difficult in terms of capacity (Tietje and Tapkenhinrichs, 1993), statistically expressed pedotransfer functions (PTF) are currently used for the indirect estimation of hydrolimits. The apparent correlation between $\Theta(h), K(h)^{2}$ and the content of individual soil grain-size fractions, led to the formulation of an empirical model - the so-called pedotransfer function (PTF) correlated to easily measured soil characteristics (granularity, specific weight, humus content, etc.) and hydrophysical soil characteristics (Gupta and Larson, 1979; Bouma, 1989; Pachepsky et al., 1996; Lamorski et al., 2008). The data most commonly used for the PTF are easy-tomeasure and usually readily available soil data, usually particle size, bulk density and organic carbon, but also the morphometric parameters of the environment (relief, slope, climate, etc.). Most empirical regional PTFs for the territory of Slovakia use multiple linear regression models for the estimation of the hydrophysical parameters of soils, which estimate soil retention properties for selected components of the analytical equation of soil retention line (Š́tor and Štekauerová, 1999; Houšková, 2000; Štekauterová et al., 2002).

The listed pedotransfer functions are deficient for the complex evaluation of soil cover due to disagreements about attributes, so that they cannot be directly used for the vector database of classified soil-ecological units of the Slovak Republic. Therefore, we have created a model algorithm from the selected parameters compatible with the vector database of classified soil-ecological units, which also allows the spatial distribution of the cumulative coefficient of water retention capacity (CWRC) for the soils of the Slovak Republic to be mapped. In this paper, we present possibilities for the interpretation of the selected parameters of the classified soil-ecological units in the quantification of water retention capacity of soils in the model areas of Levoča and Hriňová cadastres.

\section{Material and methods}

The process of developing an algorithm for the assessment of the water retention capacity of soils is presented in this section. We developed an algorithm for the quantification of water retention capacity of soils (WRC) using a suitable combination of the parameters of classified soil-ecological units (basic attributes of soil subtype, soil profile depth, granularity) and selected morphometric conditions of the environment (slope in combination with aspect).

The assessment of soil water retention capacity (WRC) was based on:

- the selected parameters of vector databases of classified soil-ecological units (M 1:10000) (NPPC, 2014) (Džatko, 2002) - granularity, soil profile depth and selected attributes of relief (slope); and

- a special purpose classification of soils of the Slovak Republic that determines the soil quality coefficient for individual soil subtypes in three basic granularity categories in the databases of classified soil-ecological units. Based on the assessment of production, buffering and retention soil functions, we determined the resulting cumulative coefficient of soil quality (for 336 soil units in three basic granularity categories occurring in the Slovak Republic - see Tab. 1)

The soil units assessed in terms of soil quality were the soil subtypes of the Morphogenetic classification system of the SR (VÚPOP, 2000) to which we added also the grain characteristics in three categories (clayey to loamy-clayey, loamy to sandy-loamy, loamy-sandy to sandy). In total, we reconsidered 336 soil units. The following Table 2 provides an example of the method of assessing the soil subtypes. The overall assessment of soil quality in the tabular input matrix was processed using factor analysis (FA) (Krnáčová and Krnáč, 1995). The input data matrix represented the database with 336 soil subtypes in 3 granular categories and with the evaluation of 3 ecological functions on a 5-degree scale. By the reassessment of the number of elements selected by the three ecological criteria on the 5-degree scale, we obtained 125 theoretically possible combinations. The determination of the final number of soil quality classes is based on the degree of similarity of the number combinations labelling the values of the environmental functions for the individual soil subtypes (Tab. 1). Quantification of the similarity of the values of the ecological functions is determined by the calculation of a correlation matrix generated from the input data matrix. According to the Malinowski error analysis, the next step determines the number of significant eigenvalues (or number of extracted factors), which means determining the number of soil quality classes with similar values of the ecological functions.

According to the interval of factor score values for the individual soil units and the given number of significant factors (number of associated soil quality classes), we have assigned each soil unit a final classification in quality classes. Table 1 shows an example of the final categorisation of soil quality according to environmental functions.

\footnotetext{
${ }^{1} \mathrm{pF}=-\log 10(\mathrm{~cm})$

${ }^{2} \theta$ is the soil water content $\left(\mathrm{cm}^{3} \times \mathrm{cm}^{-3}\right)$; $\mathrm{K}$ is hydraulic conductivity $\left(\mathrm{cm} \times\right.$ day $\left.^{-1}\right)$; h is soil water pressure head $(\mathrm{cm})$
} 


\subsection{Attribute characteristics of classified soil-ecological units}

In terms of soil and ecology, the classified soil-ecological units are relatively the most homogenous units of the land evaluation information system. In fact, they represent the main soil-climatic units that are further divided according to the categories of their slope gradient, aspect, skeleton, soil depth and the granularity of the surface horizon. Each classified soil-ecological unit is identified and its soilclimatic properties are expressed by a combination of codes of individual properties at fixed positions in a 7-digit code.
Given the scope and chronology of mapping and evaluation of all agricultural soils in the SR, the soil database may include certain inaccuracies that need to be removed during the process of the Land Evaluation Information System update. Reasons of such inaccuracies were objective and subjective. Objective errors were caused by the inaccuracy of planimetry and by the elevation of base maps that result in the wrong determination of slope and aspect codes, but they are eliminated by using the digital model relief (DMR) generated from the focus of elevation in land consolidation

\begin{tabular}{|c|c|c|c|c|c|c|}
\hline Soil types & Soil subtypes & Soil species & 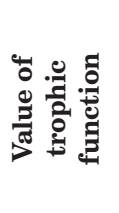 & 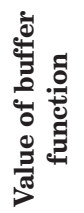 & 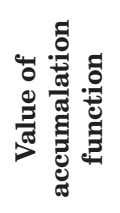 & 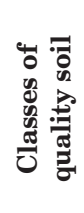 \\
\hline Lithic Leptosols & & - & 1 & 1 & 1 & 1 \\
\hline \multirow[t]{17}{*}{ Skeletic Leptosols } & Lithic Leptosols & $\mathrm{I}-\mathrm{IH}$ & 1 & 1 & 1 & 1 \\
\hline & & $\mathrm{H}-\mathrm{PH}$ & 1 & 1 & 1 & 1 \\
\hline & & HP-P & 1 & 1 & 1 & 1 \\
\hline & Rendzi-Lithic Leptosols & $\mathrm{I}-\mathrm{IH}$ & 1 & 2 & 2 & 2 \\
\hline & & $\mathrm{H}-\mathrm{PH}$ & 1 & 2 & 2 & 2 \\
\hline & & HP-P & 1 & 1 & 1 & 1 \\
\hline & Foli-Skeletic Leptosols & I-IH & 2 & 2 & 2 & 3 \\
\hline & & $\mathrm{H}-\mathrm{PH}$ & 2 & 2 & 2 & 3 \\
\hline & & HP-P & 1 & 1 & 1 & 1 \\
\hline & Skeletic (Skeli- Leptosols Dystric) & $\mathrm{H}-\mathrm{PH}$ & 2 & 3 & 3 & 5 \\
\hline & & HP-P & 2 & 2 & 2 & 3 \\
\hline & Cambi-Eutric Leptosols & $\mathrm{I}-\mathrm{IH}$ & 2 & 3 & 2 & 4 \\
\hline & & $\mathrm{H}-\mathrm{PH}$ & 2 & 3 & 3 & 5 \\
\hline & & HP-P & 2 & 2 & 2 & 3 \\
\hline & Tephri-Skeletic Leptosols & $\mathrm{I}-\mathrm{IH}$ & 2 & 3 & 3 & 5 \\
\hline & & $\mathrm{H}-\mathrm{PH}$ & 2 & 3 & 3 & 5 \\
\hline & & HP-P & 2 & 3 & 2 & 4 \\
\hline \multirow[t]{16}{*}{ Eutric Regosols } & Skeletic (Skeli-Dystric) Leptosols & $\mathrm{I}-\mathrm{IH}$ & 1 & 2 & 1 & 1 \\
\hline & & $\mathrm{H}-\mathrm{PH}$ & 1 & 2 & 2 & 2 \\
\hline & & HP-P & 1 & 2 & 1 & 1 \\
\hline & Eutric Regosols Dystric & $\mathrm{I}-\mathrm{IH}$ & 1 & 2 & 2 & 2 \\
\hline & & $\mathrm{H}-\mathrm{PH}$ & 2 & 2 & 2 & 3 \\
\hline & & HP-P & 1 & 1 & 1 & 1 \\
\hline & Calcaric Regosols & I-IH & 2 & 3 & 2 & 4 \\
\hline & & $\mathrm{H}-\mathrm{PH}$ & 2 & 3 & 3 & 5 \\
\hline & & HP-P & 2 & 3 & 2 & 4 \\
\hline & Eutric Regosols & I-IH & 2 & 3 & 2 & 4 \\
\hline & & $\mathrm{H}-\mathrm{PH}$ & 3 & 3 & 3 & 6 \\
\hline & & $\mathrm{HP}-\mathrm{P}$ & 2 & 2 & 2 & 3 \\
\hline & Spodic Regosols & I-IH & 1 & 1 & 1 & 1 \\
\hline & & $\mathrm{H}-\mathrm{PH}$ & 2 & 1 & 2 & 2 \\
\hline & & HP-P & 1 & 1 & 1 & 1 \\
\hline & Stagnic Regosols & I-IH & 1 & 1 & 1 & 1 \\
\hline
\end{tabular}

Tab. 1: An example of the final categorisation of soil quality according to environmental functions. Notes: I-IH = clayclay loam, H-PH = loam-sandy loam, HP-P = loam sandy-sandy. Source: Krnáčová, 2010 
projects (LCP). Other inaccuracies arise as a result of human activities that significantly affect soil-forming processes (erosion, drainage, etc.) or completely change the initial configuration of the natural soil profile (reclamation, tillage, terracing, etc.). For these reasons, the Land Evaluation Information System was updated at a level of the soilecological unit classification system.

This update included a revision of basic pedological field research, in which changes occurred at the level of main soil units based on pedological probes and their morphological, chemical and physical analyses. Based on this update, the dial was innovated (main soil units were extended to a final number of 100 , while a new 7-digit code was introduced into the classification of soil-ecological units, which includes soilclimatic characteristics expressed as a combination of the codes of individual characteristics at fixed positions of the resulting 7-digit code). The total number of classified soilecological units innovated by the Land Evaluation Information System generated more than 6500 codes (Linkeš et al., 1996).

\subsection{Program-technical characteristics of the map database of classified soil-ecological units}

The database is transformed into the universal vector format DXF and into the format of the environment of the program system GIS: ARC/INFO. It is thus usable by all types of GIS working with the DXF format.

\begin{tabular}{|c|c|c|c|c|c|c|}
\hline \multirow{2}{*}{$\begin{array}{c}\begin{array}{c}\text { Number of } \\
\text { soil units } \\
\text { (SU) }\end{array} \\
1\end{array}$} & \multicolumn{4}{|c|}{$\begin{array}{l}\text { Real combination values } \\
\text { of environmental functions }\end{array}$} & \multirow{2}{*}{$\begin{array}{c}\begin{array}{c}\text { Coefficient of } \\
\text { quality of soil units } \\
\text { (CQSU) }\end{array} \\
1\end{array}$} & \multirow{2}{*}{$\begin{array}{l}\text { Identification and description of soil class } \\
\text { Soils with very low trophism value, with a very small buffer } \\
\text { system with very low accumulation capacity }\end{array}$} \\
\hline & 1 & 1 & 1 & 1 & & \\
\hline & 1 & 2 & 1 & 1 & & \\
\hline & 1 & 1 & 2 & 1 & & \\
\hline & 1 & 2 & 2 & 2 & 2 & $\begin{array}{l}\text { Soils with very low to low trophism value, with a very weak to } \\
\text { weak buffer system and very low to low accumulation capacity }\end{array}$ \\
\hline & 2 & 2 & 1 & 2 & & \\
\hline & 2 & 1 & 2 & 2 & & \\
\hline & 2 & 2 & 2 & 3 & 3 & $\begin{array}{l}\text { Soils with low trophism value, with a weak buffer system with } \\
\text { low accumulation capacity }\end{array}$ \\
\hline & 2 & 3 & 2 & 4 & 4 & $\begin{array}{l}\text { Soils with low to medium trophism value, a weak to moderately } \\
\text { strong buffer system with low to moderate accumulation capacity }\end{array}$ \\
\hline & 2 & 2 & 3 & 4 & & \\
\hline & 3 & 2 & 2 & 4 & & \\
\hline & 2 & 4 & 2 & 5 & 5 & $\begin{array}{l}\text { Soils with low to medium trophism value, with a moderate-to- } \\
\text { high buffer system with low to moderate accumulation capacity }\end{array}$ \\
\hline & 2 & 3 & 3 & 5 & & \\
\hline & 3 & 3 & 2 & 5 & & \\
\hline & 2 & 4 & 3 & 6 & 6 & $\begin{array}{l}\text { Soils with mean trophism value, with a moderate to high buffer } \\
\text { system and medium to high accumulation capacity }\end{array}$ \\
\hline & 3 & 3 & 3 & 6 & & \\
\hline & 3 & 2 & 4 & 6 & & \\
\hline & 2 & 3 & 5 & 7 & 7 & $\begin{array}{l}\text { Soils with mean trophism value, with a moderate to high } \\
\text { buffer system and moderate to very high accumulation capacity }\end{array}$ \\
\hline & 3 & 4 & 3 & 7 & & \\
\hline & 3 & 3 & 4 & 7 & & \\
\hline & 4 & 3 & 3 & 7 & & \\
\hline & 3 & 4 & 4 & 8 & 8 & $\begin{array}{l}\text { Soils intermediate with high trophism value, high buffer } \\
\text { system, and medium to high accumulation capacity }\end{array}$ \\
\hline & 4 & 4 & 3 & 8 & & \\
\hline & 4 & 4 & 4 & 9 & 9 & $\begin{array}{l}\text { Soils with high trophism value, high to very high buffering } \\
\text { system, and high accumulation capacity }\end{array}$ \\
\hline & 4 & 5 & 4 & 9 & & \\
\hline & 4 & 5 & 4 & 9 & & \\
\hline & 4 & 4 & 5 & 10 & 10 & $\begin{array}{l}\text { Soils with high trophism value, high to very high buffer system } \\
\text { and very high accumulation capacity }\end{array}$ \\
\hline & 4 & 5 & 5 & 10 & & \\
\hline 336 & 5 & 5 & 5 & 11 & 11 & $\begin{array}{l}\text { Soils with very high trophism value, with very high buffer } \\
\text { system, and very high accumulation capacity }\end{array}$ \\
\hline
\end{tabular}

Tab. 2: Coefficient of quality (CQSU) of soil units defined as an output of a special purpose SR soil classification Source: Krnáčová, 2010 


\subsection{Interpretation of classified soil-ecological units}

Creating the algorithm, we based it upon the pedotransfer rule. This is based on an assumption, which is also confirmed by direct measurements of $\mathrm{pF}$ values: the higher the clay fraction percentage in soil compared to the dust and especially the sand fraction, the higher the water storage capacity, and thus also the higher water retention capacity. It is similar for soil depth: the deeper the soil, the more water can be accumulated in its profile. Morphometric characteristics of the relief, namely slope, are also important in affecting the soil retention capacity.

This procedure can be written in the following logistic form:

$$
C W R C_{\text {soils }}=\left[\left(C Q S U_{1-1}\right) \cdot\left(G_{1-5}\right)\right] \cdot R_{0-9}
$$

where $\mathrm{CWRC}_{\text {soils }}=$ Coefficient of soils water retention capacity, CQSU- = Coefficient quality of soil unit in SEU database, $\mathrm{G}=$ Category of soil granularity (clay content in $\%)$, and IR = Index of the relief (slope).

The output is a cumulative CWRC index by which we can review all the main mapping soil units regarding classified soil-ecological units in the Slovak Republic.

The range for the individual categories $(0.1-11)$ is given by the results of the factor analysis (FA) and the number of 11 significant factor loadings that indicated the number of 11 soil quality classes out of 125 possible combinations of the selected ecological criteria. The range of intervals for individual categories of the cumulative CWRC index was divided into 10 categories in Table 3.

In order to evaluate the potential of soils to accumulate water, we selected the categorisation of water supplies derived from the field water capacity (FWC) (in $\mathrm{mm}$ ). The above categorisation comes from the Bujnovský et al. (2009) study, where the FWC values $\left(\mathrm{cm}^{3} \times \mathrm{cm}^{3}\right)$ were aggregated by granular categories of the digital layer of classified soilecological units according to the individual soil-ecological regions. Thus, during the evaluation of soil retention capacity, also the spatial granularity distribution was taken into account. Subsequently, the values were recalculated according to the categorisation of classified soil-ecological units with respect to soil depth to the potential of their water accumulation in mm of water column (see examples given later for the case study areas, Tabs. 5 and 6).

\subsection{Interpretation of selected attributes of classified soil- ecological units using the algorithm and their projection into the vector database of SEU polygons}

The created algorithm (Tab. 4) was projected into the vector polygons of classified soil-ecological units (Fig. 1) for the example of the selected model area of the town of Hriňová, which is discussed in detail in the next section.

\section{Results and discussion}

\subsection{The model area of the Hriňová town cadastre}

The model area of Hriňová administratively belongs in the Banská Bystrica region and in the Detva district (the Hron River basin). A part of the cadastral area belongs in the Protected Landscape Area - Biosphere Reservation Pol'ana. The area is delimited by the cadastral border and covers the urban area of the municipality and adjacent meadow, pasture, arable land and forest areas. The vast forest complexes are dominant, especially at higher altitudes.

The diversity of relief, mineral substrates and the considerable humidity of the area determined the emergence and development of a specific spectrum of soils. The geological-relief conditions of the area, together with mainly climatic, hydrological and vegetation factors, also strongly differentiated the soil cover and its character.

\begin{tabular}{lcc}
\hline CWRC category & $\begin{array}{c}\text { Numerical } \\
\text { designation of } \\
\text { categories }\end{array}$ & $\begin{array}{c}\text { Range of CWRC } \\
\text { value }\end{array}$ \\
\hline Very low & 1 & $0.10-0.19$ \\
Low & 2 & $0.20-2.28$ \\
Medium & 3 & $2.29-3.37$ \\
& 4 & $3.38-4.56$ \\
High & 5 & $4.57-5.55$ \\
& 6 & $5.56-6.64$ \\
Very high & 7 & $6.65-7.73$ \\
& 8 & $7.74-8.82$ \\
& 9 & $8.83-9.91$ \\
\hline
\end{tabular}

Tab. 3: Categories of cumulative CWRC index values Source: authors' calculation

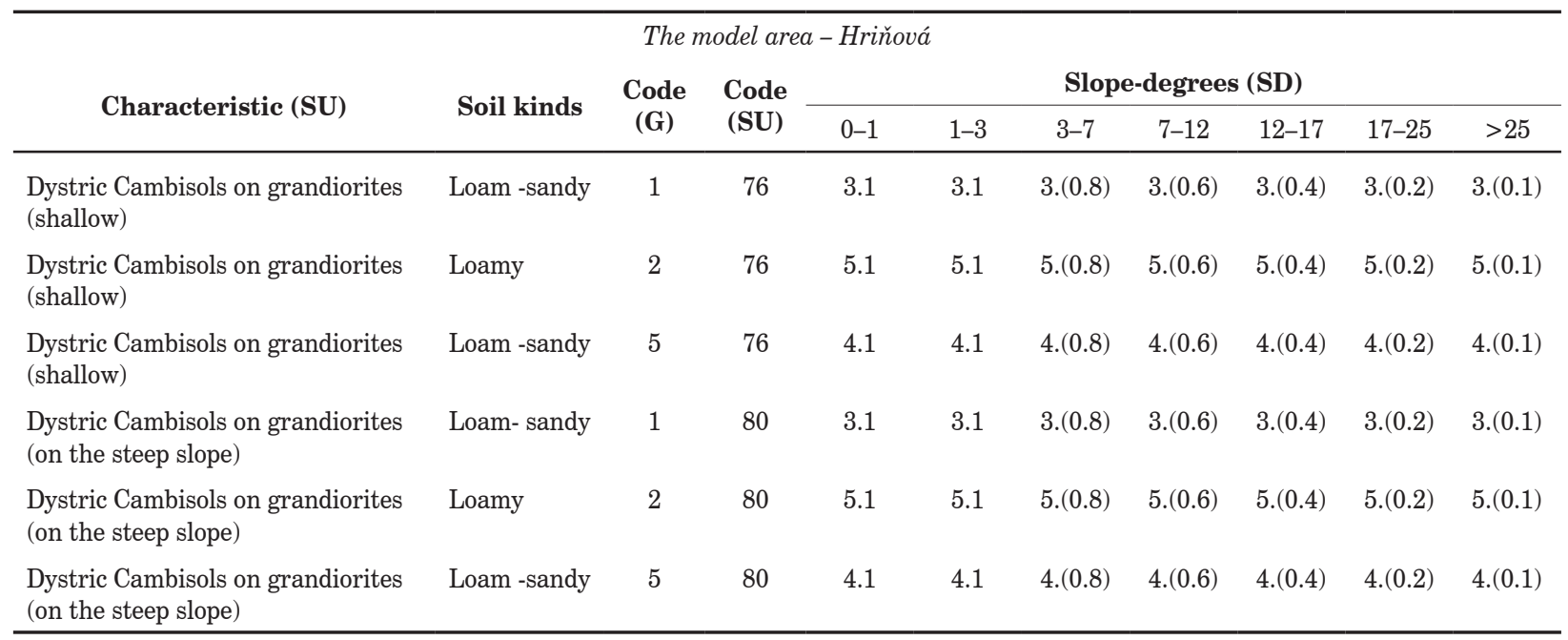

Tab. 4: Algorithm of CWRC quantification (part of algorithm)

Legend: SU - main soil units, $G$ - granularity. Source: authors' calculation 


\subsection{Retention capacity of the soil cover}

Quaternary sediments in the form of gravelly fluvial sediments along watercourses conditioned the emergence of fluvial soils of modal and gley that are on cultivated soils anthropogenically altered into anthrosol fluvial soils. Anthrosol fluvial soils, loamy with values (CWRC 6.65-9.91) were included with soils of high and very high retention capacity. Gley loamy fluvial soils (CWRC 4.57-5.55) have medium retention capacity. Similarly, clayey-loamy types of fluvial soils are characterised by relatively good water retention, indicating that the soil is capable of storing quite a large quantity of water together with solutes in the soil profile. It should be noted, however, that with the increasing representation of a clay fraction in the soil profile, the water

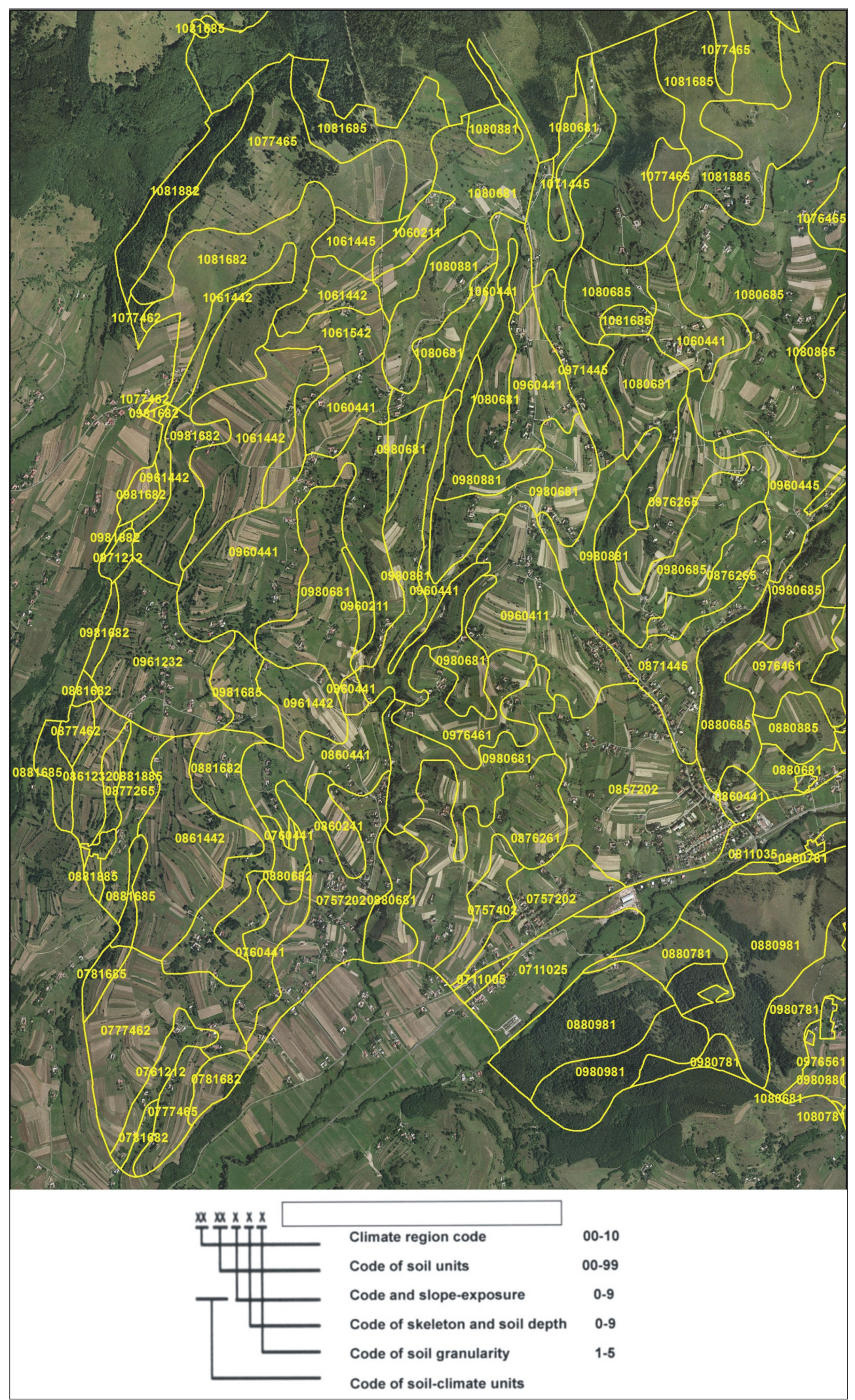

Fig: 1: SEU vector database (1:10,000) for the Hriňová model area 
storage capacity of soils (retention capacity) increases too, but so does the proportion of biologically unusable water. Hence, the landscape hydric potential increases, but the usability of the soil water for plants decreases.

The prevailing acidic rocks (grandiorites, biotic diorites, as well as volcanic rocks in the northern and northwestern parts of the territory) (Miklós, 2002) together with the forests, conditioned the emergence of modal cambisols that have been altered in the deforested areas by human agricultural activity into anthrosolic cambisols. Cambisols are the most common soil type in the examined area. They occupy nearly $90 \%$ of the land area. The agrarian landscape features a wide range of cambisols on diverse substrates.

Medium and higher values of water retention capacity (CWRC 4.57-6.64) were achieved by anthrosolic cambisols, deep and moderately deep, loamy on crystalline rocks, volcanic and other substrates. Their sandy-loamy varieties (CWRC 2.29-4.56) have lower water storage capacity, and thus also lower retention capacity. The southern part of the agrarian landscape features quite extensive occurrence of anthrosolic pseudogley on loess loams. Loamy types have a high WRC (CWRC 5.55-6.64). Pseudogley on polygenic loams, loamy, had lower values falling within the CWRC interval 3.37-4.56.

Only a small part of the territory at the southern border of the cadastre is covered by anthrosolic rendzinas bound to more basic geological substrate with medium to high WRC values (CWRC 4.46-6.64). These are soils with a high proportion of quality organic substances; however, the high proportion of skeleton in their soil profile reduces the total water storage capacity and thus also the WRC. Organosols occur occasionally too. Organosols are characterised by the deep peat horizon with high accumulation of organic substances. In terms of retention, organosols represent an important water reservoir in the landscape. Their CWRC values ranged from 8.82 to 9.91 , i.e. soils with high to very high retention capacity.

The area outside continuous forests in the cultivated landscape, features light sandy to loamy-sandy soils, sometimes even moderately heavy loamy to sandy-loamy soils. The soils are predominantly medium-skeletal, only locally strongly skeletal. It follows that given the prevailing occurrence of cambisols with a smaller proportion of clayey fractions, we can include the hydric soil potential into the category of low retention capacity (Fig. 2). The overview of surface area actually occurring in the soil WRC category is presented in Table 5.

Land use and management are very important in terms of total landscape hydric potential. In terms of land use in 2010, the largest share of the cadastral area was taken by forest elements and semi-natural sites, which accounted for $72 \%$

\begin{tabular}{lcccc}
\hline $\begin{array}{c}\text { Categories of water } \\
\text { retention capacity } \\
\text { (WRC) }\end{array}$ & $\begin{array}{c}\text { Degrees of water } \\
\text { retention capacity } \\
\text { (WRC) }\end{array}$ & Area $\left(\mathbf{m}^{\mathbf{2}}\right)$ & Area (\%) & $\begin{array}{c}\text { Categories } \\
\text { of water resources } \\
\text { (derived from FWC) }\end{array}$ \\
\hline Very Low & 1 & $4,314,640.54$ & 11.49 & $\leq 100 \mathrm{~mm}$ \\
& 2 & $14,623,637.84$ & 38.94 & \\
Low & 3 & $10,019,588.83$ & 26.68 & $101-200 \mathrm{~mm}$ \\
& 4 & $6,477,937.38$ & 17.25 & \\
Moderate & 5 & $2,114,911.23$ & 5.63 & $201-300 \mathrm{~mm}$ \\
\hline
\end{tabular}

Tab. 5: Areas of the currently occurring WRC soil categories (Hriňová). Legend: FWC - categorisation of water resources derived from the full water capacity of water level height in the soil profile. Source: authors' calculation

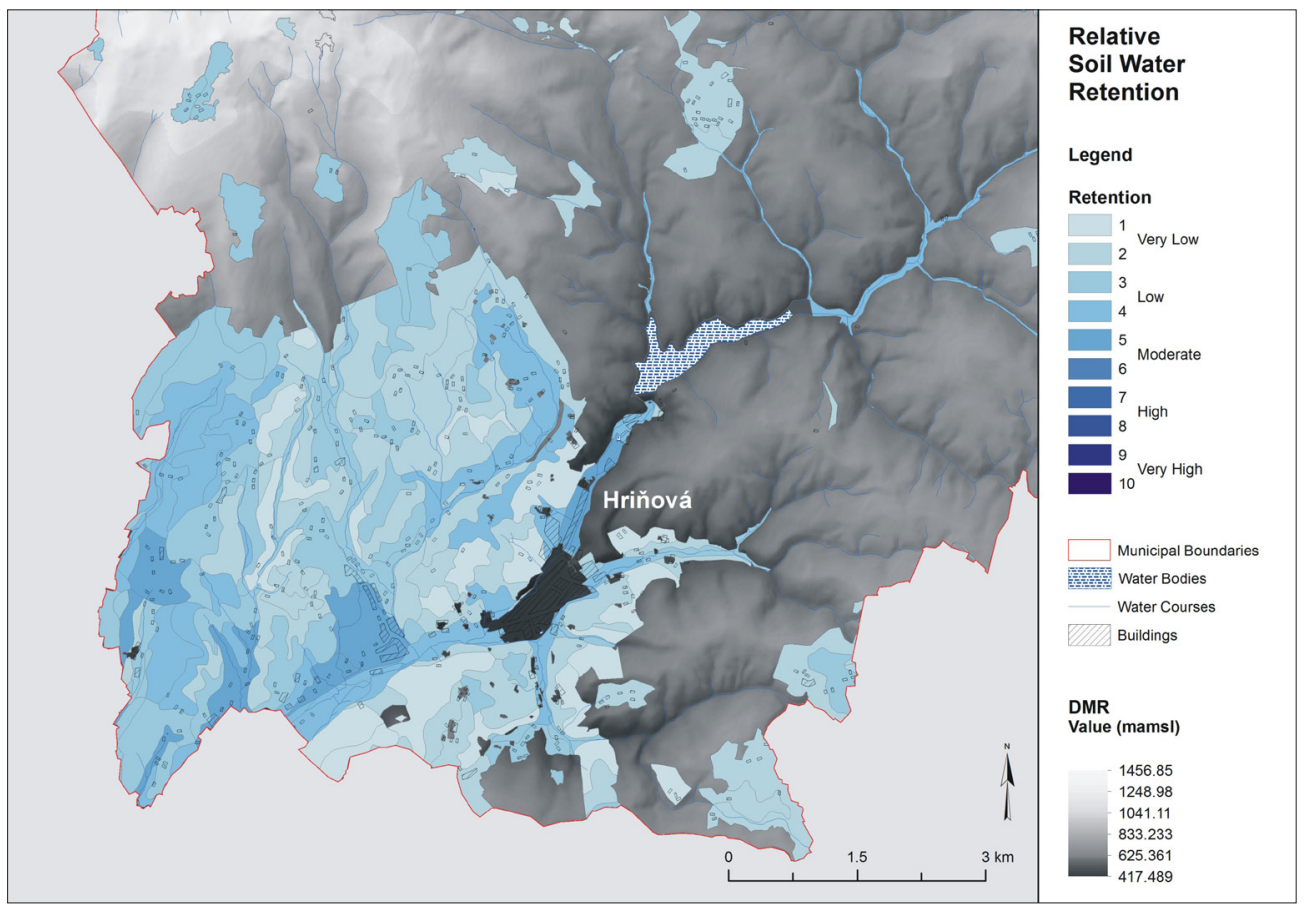

Fig. 2: WRC of soil cover in the Hriňová model area. Source: authors' elaboration 
of the area (9,143.65 ha) (Mojsej and Petrovič, 2013). The second largest group in the current landscape structure was represented by agricultural land elements, which accounted for nearly L' of the cadastral area (23.53\% - 2,974.81 ha). The greatest part of the agricultural land was localised in the SW part of the area. The largest area consisted of a mosaic of arable land with permanent grasslands (with non-forest woody vegetation up to 20\%) (Petrovič and Mojsej, 2011).

The mosaics of arable land and grasslands create important eco-stabilising, soil-protecting and hydric-effective elements in the landscape. Stabilisation, revitalisation and respect for the principles of sustainable management may lead to a more balanced hydrological cycle in the landscape (Antal et al., 1989).

\subsection{Retention capacity of the soil cover in the Levoča town cadastre}

The geological base consists of sandstone and shale strata widespread in the peripheral parts of the Levoča Mountains. Alternating are massive sandstone benches (thickness 30-150 cm) with calcareous shales on the southern and western margin of the mountains (Gross, 1999). Soils are predominantly saturated modal cambisols, loamy to sandy-loamy. The water retention capacity of these soil complexes reaches in terms of their parameters a relatively moderate value within the CWRC interval 5.55-6.64. The dominant part of the landscape relief consists of hilly relief, moderately to strongly ragged on deluvial sediments with the prevailing occurrence of anthrosolic cambisols, loamy, in complexes on more basic substrates with pararendzinas. Their value ranges from 5.56 to 7.73 , which is a medium CWRC value. In the western and northwestern parts of the area, shallow cambisols developed on flysch substrates, loamy to clayey-loamy with a low value of water retention capacity in the CWRC range from 2.29 to 3.37. Shallow cambisols on flysch substrates occupy quite large areas in this part of the area and their retention capacity is low. They are intensively agriculturally used and unthrifty use and poor agronomic management can lead to increasing surface runoff and increased water erosion. On more defined slopes, regosols developed locally, strongly skeletal, loamy and sandy-loamy, whose CWRC is $0.20-2.28$. These soils have a very low retention capacity, and therefore the use and management of the landscape are crucial. They are usually used as extensive meadows and pastures, which optimises the hydrological regime of the landscape.

Fluvial sediments along watercourses consist of pebbles, sands and silty loams, on which a fairly wide range of fluvial soils developed. In the southern part of the area, in the basin of Levoča River tributaries, there are anthrosolic fluvial soils, clayey-loamy. Their water storage capacity with respect to optimum physical parameters reaches relatively the highest CWRC values in the area, in the range 6.64-7.73.

A relatively high retention capacity is also achieved by carbonate fluvial soils, clayey-loamy in the basin of the Levoča R., in the southern part of the territory. Gley fluvial soils of moderate to heavy weight with respect to the high groundwater level in the soil profile exhibit a relatively lower water storage capacity that ranges from 5.55 to 6.64 . The locally-present rendzinas on carbonate, loamy to clayeyloamy substrates, are characterised by medium CWRC values ranging within the interval 4.57-6.64.

On more defined slopes of carbonate rocks, shallow rendzinas developed, usually strongly skeletal, clayeyloams with the relatively lowest water storage capacity (CWRC 0.20-3.37). An overview of areas of soil WRC categories can be seen in Table 6 and their spatial representation is shown in Figure 3.

With regard to the localities with more ragged and sloping relief in the evaluated area, where the soil cover reaches lower CWRC values, agricultural management is very important. In the cadastral area of the Levoča town with an acreage of 6,404 hectares, agricultural land represents 3,226 ha $(57.37 \%)$, of which 1,752 ha $(27.35 \%)$ is arable land, 1,263 ha (19.72\%) are pastures and meadows,

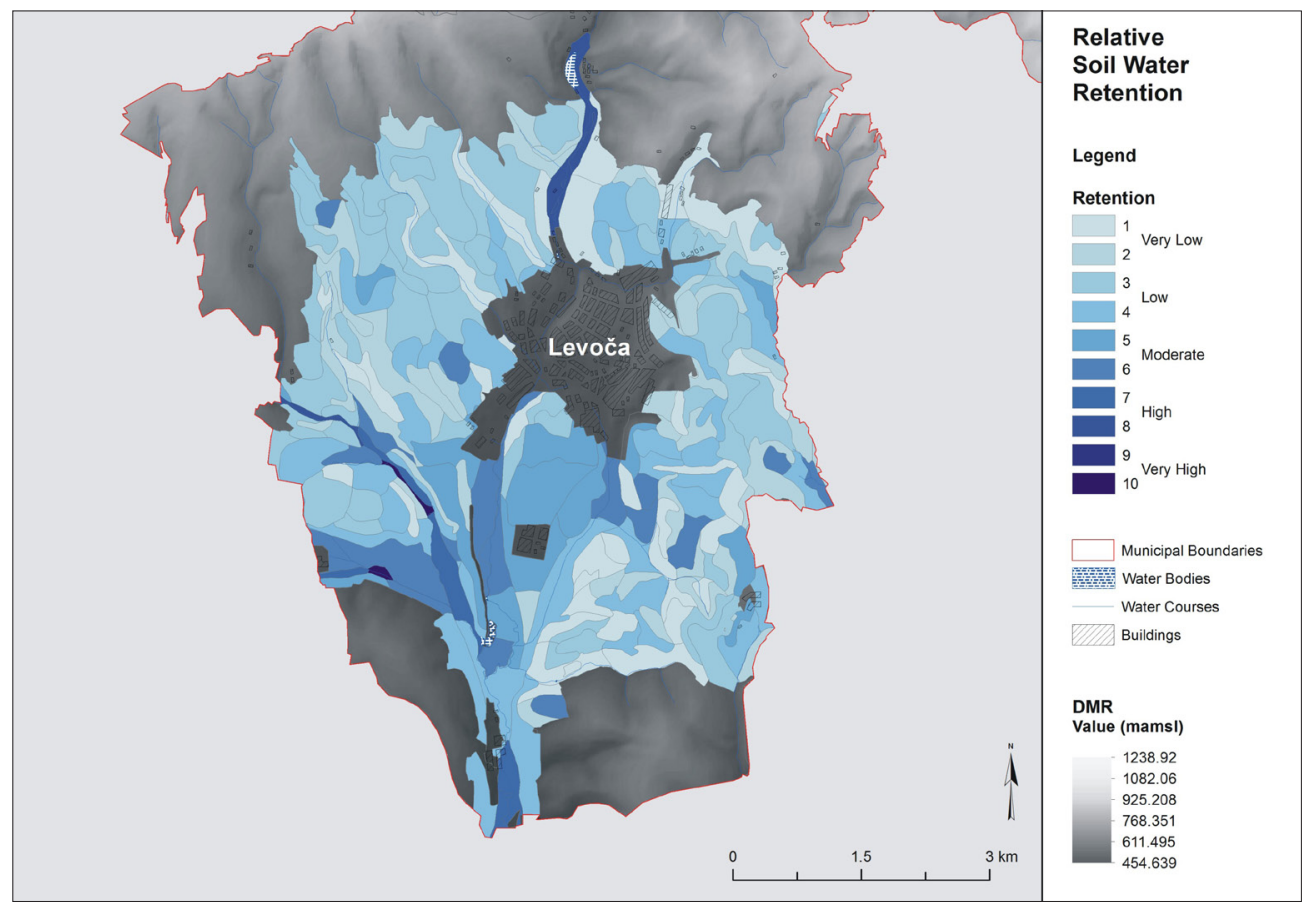

Tab. 6: Areas of the curently occurring WRC soil categories (Levoča). Legend: FWC-categorisation of water resources derived from the full water capacity of water level height in the soil profile

Source: authors' calculation 


\begin{tabular}{lcccc}
\hline $\begin{array}{c}\text { Categories of water } \\
\text { retention capacity } \\
\text { (WRC) }\end{array}$ & $\begin{array}{c}\text { Degrees of water } \\
\text { retention capacity } \\
\text { (WRC) }\end{array}$ & Area $\left(\mathbf{m}^{2}\right)$ & Area (\%) & $\begin{array}{c}\text { Categories } \\
\text { of water resources } \\
\text { (derived from FWC) }\end{array}$ \\
\hline Very low & 1 & $4,698,761.88$ & 15.60 & $\leq 100 \mathrm{~mm}$ \\
Low & 2 & $4,549,070.60$ & 15.10 & \\
& 3 & $8,137,923.78$ & 27.01 & $101-200 \mathrm{~mm}$ \\
Moderate & 4 & $6,213,347.43$ & 20.62 & \\
& 5 & $2,866,672.72$ & 9.52 & $201-300 \mathrm{~mm}$ \\
High & 6 & $2,539,433.03$ & 8.43 & \\
& 7 & $624,046.27$ & 2.07 & $301-400 \mathrm{~mm}$ \\
Very High & 8 & $429,493.79$ & 1.43 & \\
\hline
\end{tabular}

Fig. 3: WRC of soil cover in the Levoča model area. Source: authors' elaboration

and forest land represents 2,544 ha (39.72\%). Sound agronomic procedures applied on arable land and a relatively high proportion of permanent grasslands create good soilprotecting conditions, which determines a more balanced hydrological cycle in the landscape.

\subsection{General comparison of results from the two studied territories}

The overall retention capacity of the model territories can be compared in terms of the calculated areas for the individual RWC categories. The model territory of Levoča has more extensive areas of cultisolic loamy cambisols in the medium RWC category, representing 18\% of the total area of agricultural land (PPF), as compared with the Hriňová model territory, where this category makes up only 5.6\% of the area. The representation of very low to low soil RWC category is $31 \%$ and $47 \%$ in the Levoča area, in comparison with the Hriňová area, where these categories represent 50\% and $44 \%$. The overall quite high representation of soils with low retention capacity in both areas is determined by the geomorphology of the area. The soils with medium and higher retention capacity in both model areas consist of loamy fluvisols in the floodplains of local watercourses and, in the Hriňová area, cambisols on volcanic substrates.

\section{Summary of the international science in pedotransfer functions (PTF)}

Research on predictive functions that derive soil properties that are difficult or expensive to measure from easily or routinely measured soil properties, is on the rise. Bouma (1989) introduced the term 'pedotransfer function' (PTF) for such predictive functions. Recently published reviews on PTF development and use include those of Pachepsky et al. (1999), Wősten et al. (2001) and Pachepsky and Rawls (2005). Databases of different sizes, scales and detail are available to develop PTFs that predict soil hydraulic properties; see Wösten et al. (2001). Many studies compare and/or validate the performance of different PTFs. Recent publications on the issue include those of Kern (1995), Tietje and Hennings (1996), Schaap and Leij (1998), Imam et al. (1999), Cornelis et al. (2001), Wagner et al. (2001), and Minasny and McBratney (2002). Some studies go further and evaluate the functionality of PTFs (e.g. Wősten et al., 1999; Hack-ten Broeke and Hegmans, 1996; van Alphen et al., 2001; Nemes et al., 2003; Soet and Stricker, 2003). Studies that belong in the first group evaluate how well certain functions predict water retention (or hydraulic conductivity), whereas the second group of studies evaluates the performance of predicted soil hydraulic characteristics through the simulation of some practical aspects of soil behaviour.

A major obstacle to the wider application of water simulation models is the lack of readily accessible and representative soil hydraulic properties. To overcome this apparent lack of data, a project was initiated to bring together hydraulic data on soils available from different institutions in Europe into one central database. This information was used to derive a set of pedotransfer functions that can provide a satisfactory alternative to the costly and time-consuming direct measurements.

A total of 20 institutions from 12 European countries collaborated in establishing the database of Hydraulic Properties of European Soils (HYPRES). As a consequence, it was necessary to standardise both the particle size and the hydraulic data. Standardisation of hydraulic data was achieved by fitting the Mualem-van Genuchten model parameters to the individual $\theta(\mathrm{h})$ and $\mathrm{K}(\mathrm{h})$ hydraulic properties stored in HYPRES.

The HYPRES database contains information on a total of 5,521 soil horizons. Each soil horizon was allocated to one of 11 possible soil textural/pedological classes derived from 6 FAO texture classes (5 mineral and 1 organic) and two pedological classes (topsoil and subsoil) recognised within the 1:1,000,000 Soil Geographical Database of Eurasia. Then, both class and continuous pedotransfer functions were developed. The class pedotransfer functions were used in combination with the 1:1,000,000 Soil Database of Europe in order to determine the spatial distribution of soil water availability (Wösten, 1999).

Scenario studies are important in planning for various hazards and their prevention. Field experiments representing different management possibilities would be time consuming, costly and sometimes even risky. Exploratory ('what if?') modelling offers an alternative that is quicker and easier to execute, and may give at least indicative answers about trends that are expected to occur. Well-tested PTFs can assist and enhance such modelling, as they can provide low-cost and low-risk input data without the need to run experiments that may cause changes to our environment. Possibilities to compare such simulations with (field) measurements are limited, so one has to be careful with the interpretation of results. 
Land use is in many ways related to the amount and quality of water, biodiversity and the provision of ecosystem services. Climate change puts emphasis on soil as a particularly vulnerable resource. Soil functions including soil stability, the water cycle in the soil, balancing the amounts of nutrients and biotic integrity, are important parameters of soil fertility. Thanks to the function of carbon sequestration, soil plays a key role in mitigating climate change. Appropriate management of the soil has to prevent its degradation and erosion, to stabilise its functions and to take into account the mitigation of climate change consequences and adaptation to the climate change. The model presented in the RWC study of soil can significantly contribute to increase the quality of the methodology of land reform projects, which is in the process of development, as pointed out by Muchová et al. (2016).

\section{Conclusion}

Soil water retention capacity represents an important hydrolimit determining and affecting many other soil characteristics and functions. Natural soil retention ability represents a significant part of the mosaic of individual components of the environment and highlights the potential risk areas, regarding floods, as well as areas where this risk can be eliminated to some extent by suitable land use and landscape management. Using the parameters of the databases of classified soil-ecological units to determine WRC enables a relatively easy identification of the amount of water potentially held in agricultural soils of Slovakia. Human activity that affects soil retention capacity or the rate of water infiltration into the soil, also affects the ability of the landscape to react to the flood threat. An increase of the retention ability of the landscape is one of the basic conditions for lasting and sustainable development and the protection of water resources. It is expected that in the Slovak Republic, the current imbalance in rainfall distribution will increase in terms of time and space, which will lead to stronger effects of extreme precipitation and droughts. Therefore, the increase of water retention in the landscape is one of the primary tasks of water management, which can largely mitigate the negative effects of climatic changes, such as the decrease of groundwater resources. The objective of proper land use, and thus also its individual components, should be to preserve their mutual balance that would integrally contribute to the beneficial use of land and water resources. This would significantly eliminate the risk of flood occurrence and the landscape should have a high capacity to quickly deal with the consequences of possible floods.

\section{References}

ANTAL, J. (1999): Applied agrohydrology. Nitra, VŠP.

BEDRNA, Z. (2002): Environmental pedology. Bratislava, Veda.

BLUM, W. E. H. (1990): The challenge of soil protection in Europe. Environmental conservation, 17(1): 72-74.

BOUMA, J. (1989): Using soil survey data for quantitative land evaluation. Advances in Soil Science, 9: 177-213.

BRODOVÁ, M. (2008): Ohodnocovanie environmentálnych funkcií pol'nohospodárskej pôdy. Ekonomika pol'nohospodárstva, 8(4): 53-58.

BUJNOVSKÝ, R., BALKOVIČ, J., BARANČÍKOVÁ, G., MAKOVNÍKOVÁ, J., VILČEK, J. (2009): Hodnotenie a oceňovanie ekologických funkcií pol’nohospodárskych pôd Slovenska. Bratislava, VÚPOP.
BUJNOVSKÝ, R., JURÁNI, B. (1999): Kvalita pôdy - jej vymedzenie a hodnotenie. Bratislava, VÚPOP.

CORNELIS W. M., RONSYN, J., VAN MEIRVENNE, M., HARTMANN, R. (2001): Evaluation of pedotransfer functions for predicting the soil moisture retention curve. Soil Science Society of America Journal, 65(3): 638-648.

DŽATKO, M. (2002): Hodnotenie produkčného potenciálu polnohospodárskych pôd a pôdno-ekologických regiónov Slovenska. Bratislava, VÚPOP.

EUROPEAN COMMISSION (2006): Proposal for a directive of the European Parliament and of the Council establishing a framework for the protection of soil and amending Directive 2004/35/EC. COM(2006) 232 final. European Commission, Brussels.

GROSS, P. (1999): Regionálne geologické mapy Slovenska. Geologická mapa a vysvetlivky ku geologickej mape Popradskej kotliny, Hornádskej kotliny, Levočských vrchov, Spišsko-šarišského medzihoria, Bachurne a Šarišskej vrchoviny 1: 50,000 Bratislava, SGIDS.

GUPTA, S. C., LARSON, W. E. (1979): Estimating soil water characteristic from particle size distribution, organic matter percent, and bulk density. Water Resources Research, 15: 1633-1635.

HACK-TEN BROEKE， M. J. D， HEGMANS， J. H. B. M. (1996): Use of soil physical characteristics from laboratory measurements or standard series for modelling unsaturated water flow. Agricultural Water Management 29: 201-213.

HOUŠKOVÁ, B. (2000): Retenčná kapacita pol'nohospodárskych pôd Slovenska. Vedecké práce. Proceedings of Soil Science and Conservation Research Institute (pp. 72-78). Bratislava, VÚPOP.

IMAM, B., SOROOSHIAN, S., MAYR, T., SCHAAP, M., WÖSTEN, J. H. M., SCHOLES, B. (1999): Comparison of pedotransfer functions to compute water holding capacity using the van Genuchten model in inorganic soils. Report to IGBP-DIS Soil Data Tasks, IGBP-DIS Working Paper 22, IGBP-DIS, Toulouse, C'edex.

JURÁNI, B. (2005): Ochrana využívania pôdy a vplyv človeka. In: Štvrté pedologické dni (pp. 178-180). Bratislava, VÚPOP.

KERN, J. S. (1995): Evaluation of soil water retention models based on basic soil physical properties. Soil Science Society of America Journal, 59: 1134-1141.

KRNÁČOVÁ, Z., KRNÁČ, Š. (1995): Application of exploratory factor analysis model to agro-ecological system study. International Journal for Ecological problems of the Biosphere. Ecology, 14(2): 123-140.

KRNÁČOVÁ, Z. (2010): Special soil classification according to selected environmental functions for multifunctional evaluation of land use. In: Barančoková, M., Krajčí, J., Kollár, J., Belčáková, I. [eds.]: Landscape Ecologymethods, applications and interdisciplinary approach. (pp. 837-849). Bratislava, Institute of Landscape Ecology, Slovak Academy of Sciences.

LAMORSKI, K., PACHEPSKY, Y., SLAWINSKI, C., WALCZAK, R. T. (2008): Using Support Vector Machines to Develop Pedotransfer Functions for Water Retention of Soils in Poland. Soil Science Society of America Journal, 72(5): 1243-1247. 
LINKEŠ, V., PESTÚN, V., DŽATKO, M. (1996): Príručka pre používanie máp bonitovaných pôdno-ekologických jednotiek. Bratislava, VUPÚ.

LOVELAND, P. J., THOMPSON, T. R. E. (2002): Identification and development of set of national indicators for soil quality. R \& D Project Record P5 - 053/ PR/02. Bristol, Environment Agency.

MIKLÓS, L. (2002): Atlas krajiny Slovenskej republiky (Landscape Atlas of the Slovak Republic). Ministry of Environment of the Slovak Republic, Slovak Agency of Environment, Banská Bystrica: 94.

MINASNY, B., MCBRATNEY, A. B. (2002): The Neuro-m method for fitting neural network parametric pedotransfer functions. Soil Science Society of America Journal, 66: 352-361.

MOJSES, M., PETROVIČ, F. (2013): Land use changes of historical structures in the agricultural landscape at the local level-Hriňová case study. Ekologia, 32(1): 1-12.

MUCHOVÁ, Z., LEITMANOVÁ, M., PETROVIČ, F. (2016): Possibilities of optimal land use as a consequence of lessons learned from land consolidation projects (Slovakia). Ecological Engineering, 90: 294-306.

NEMES, A. (2003): Unsaturated soil hydraulic database of Hungary: HUNSODA. Agrokémia és Talajtan, 51(12): $17-26$.

NPPC (2014): Vektorové databázy BPEJ pre modelové územia Hriňová, Levoča (M 1:10,000). Bratislava.

PACHEPSKY, Y. A, RAWLS, W. J, TIMLIN D. J. (1999): The current status of pedotransfer functions: their accuracy, reliability and utility in field- and regional-scale modelling. In: Corwin, D. L. et al. [eds.]: Assessment of Non-point Source Pollution in the Vadose Zone, Geophysical Monograph 108 (pp. 223-234). Washington, DC, American Geophysical Union.

PACHEPSKY, Y. A., TIMLIN, D. J., VARALLYAY, G. (1996): Artificial neural networks to estimate soil water retention from easily measurable data. Soil Science Society of America Journal, 60: 727-733.

PACHEPSKY, Y. A., RAWLS, W. J. [eds.] (2005): Development of pedotransfer functions in Soil Hydrology. Developments in Soil Science, 30, Amsterdam, Elsevier.

SCHAAP, M. G, LEIJ, F. J. (1998): Database-related accuracy and uncertainty of pedotransfer functions. Soil Science, 163(10): 765-779.

SOET, M., STRICKER, J. N. M. (2003): Functional behaviour of pedotransfer functions in soil water flow simulation. Hydrological Processes, 17: 1659-1670

SWANSON, T. M., BARBIER, E. B. [eds.] (1992): Economics for the Wilds: wildlife, wildlands, diversity and development. London, Earthscan.
ŠÚTOR, J., ŠTEKAUEROVÁ, V. (1999): Určovanie bodov vlhkostnej retenčnej čiary zo základných fyzikálnych charakteristík pôdy. In: Proceedings of the III. Conference „Vplyv antropogénnej činnosti na vodný režim nížinného územia ÚH SAS, Michalovce Zemplínska Š́rava, pp. 151-157.

ŠTEKAUEROVÁ, V., SKALOVÁ, J., ŠÚTOR, J. (2002): Using of pedotransfer functions for assessment of hydrolimits. Rostlinná Výroba, 48: 407-412.

TIETJE, O., TAPKENHINRICHS, M. (1993): Evaluation of pedo-transfer function. Soil Science Society of America Journal, 57: 1088-1095.

TIETJE, O., HENNINGS, V. (1996): Accuracy of the saturated hydraulic conductivity prediction bypedotransfer functions compared to the variability within FAO textural classes. Geoderma, 69: 71-84.

VAN ALPHEN B. J, BOOLTINK H. W. G., BOUMA J. (2001): Combining pedotransfer functions with physical measurements to improve the estimation of soil hydraulic properties. Geoderma, 103: 133-147.

VÚPOP (2000): Morfogenetický klasifikační systém pôd Slovenska. Bazálná referenčná taxonomia. Bratislava.

WÖSTEN, J. H. M, PACHEPSKY, Y. A., RAWLS, W. J. (2001): Pedotransfer functions: bridging the gap between available basic soil data and missing soil hydraulic characteristics. Journal of Hydrology, 251(3-4): 123-150.

WÖSTEN, J. H. M, FINKE, P. A, JANSEN, M. J. W. (1999): Comparison of class and continuous pedotransfer functions to generate soil hydraulic characteristics. Geoderma, 66: 227-237.

WAGNER, B., TARNAWSKI, V.R., HENNINGS, V., MÜLLER, U., WESSOLEK, G., PLAGGE, R. (2001): Evaluation of pedo-transfer functions for unsaturated soil hydraulic conductivity using an independent data set. Geoderma, 102: 275-297.

WÖSTEN， J.H.M. (1999): The Hypress database of hydraulic properties of European soils Source In: Feyen, J., Wiyo, K. [eds.]: Modelling of transport processes in soils at various scales in time and space; international workshop of EurAgEng's field of interest on soil and water. Wageningen, Wageningen Pers, (pp. 675-681). Department(s) Winand Staring Centre for Integrated Land, Soil and Water Research Database of Hydraulic Properties of European Soils (HYPRES), version 1.0

YAALON, D. H., ARNOLD, W. (2000): Attitudes toward soils and their societal relevance: Then and now. Soil Science, 165(1): 5-12. 